Bangladesh Journal of Neuroscience 2008; Vol. 24 (1) : 9-16

\title{
Initial Neurologic Symptoms Among Bangladeshi Multiple Sclerosis Patients
}

\author{
MD BAHADUR ALI MIAH ${ }^{1}$, ABDUL KADER SHEIKH $^{1}$, AKHLAQUE HOSAIN KHAN², \\ MD RAFIQUL ISLAM ${ }^{3}$, AKM ANWAR ULLAH $^{4}$, QUAZI DEEN MOHAMMAD ${ }^{5}$, \\ ANISUL HAQUE ${ }^{4}$
}

\begin{abstract}
This study was undertaken in the Department of Neurology, Bangabandhu Sheikh Mujib Medical University (BSMMU), Dhaka, from January 2002 to December 2003. The objective of this study was to determine the initial neurologic symptoms of multiple sclerosis among Bangladeshi patients.

A total of 25 respondents of multiple sclerosis patients as cases selected by McDonald et al. (2001) diagnostic criteria for multiple sclerosis were enlisted during the study period. The clinical details, investigations of the respondents were reviewed. Data were recorded in predesigned data collection sheet. Out of 25 cases, male patients were 12 (48\%) and females were 13 (52\%), ratio being 1:1.08. Majority of the patients presented at second, third and fourth decades of life.
\end{abstract}

Most of the patients (56\%) had acute onset, followed by subacute (28\%) and insidious (16\%). Certain clinical characteristics among Bangladeshi multiple sclerosis patients are noteworthy, namely, number of male and female patients almost equal (48\% vs $52 \%$ ), a higher rate of impaired vision (optic nerve involvement, 64\%), motor weakness (92\%), sphincteric disturbances (92\%) and a lower rate of brainstem and cerebellar involvement. Painful tonic spasm was a prominent feature among Bangladeshi patients with multiple sclerosis (8 out of $25,32 \%$ ).

Out of 25 patients, one (4\%) expired due to aspiration pneumonia. Twenty four (96\%) survived. Among them 9 (36\%) has restricted activity, 7 (28\%) were bedridden, 5 (20\%) were chairbound, 2 (8\%) had minor disability and were in work and 1 (4\%) was completely normal.

\section{Introduction}

Multiple sclerosis (MS) is an inflammatory demyelinating disease of central nervous system (CNS) causing significant morbidity with a variable course, thought to result from immune response to myelin sheath with variability in frequency. It typically presents between the ages of 18 and 45 years, although the true onset of the disease likely predates the initial symptoms in most individuals ${ }^{1}$.

Multiple sclerosis is more frequently encountered in western countries and is distinctly unknown in certain ethnic and

1. Assistant Professor, Department of Neurology, Bangabandhu Sheikh Mujib Medical University (BSMMU), Dhaka.

2. Assistant Professor, Department of Neurosurgery, BSMMU, Dhaka.

3. Associate Professor, Department of Neurology, BSMMU, Dhaka.

4. Professor, Department of Neurology, BSMMU, Dhaka.

5. Professor and Head, Department of Neurology, Dhaka Medical College and Hospital, Dhaka. 
racial groups, such as Eskimos, Native Americans, Indians and Africans ${ }^{2}$. The variation in prevalence of MS according to geographical location and the modification of clinical picture by ethnic groups are all well known features of the disease ${ }^{3}$. Current estimates suggest that the prevalence in the United States is approximately 350,000 with an annual incidence of about $12,000^{4}$. Prevalence is low in Saudi Arabia and other Arab Middle Eastern countries with rates varying between 4 and 12 per 100,000 inhabitants ${ }^{5-}$ 7 . In contrast amongst Caucasians rate is as high as 309 per 100,000 have been reported $^{8,9}$. It was thought that MS was uncommon in Bangladesh and other tropical and sub-tropical countries ${ }^{10-12}$. Susceptibility is also associated with particular genetic factor, such as HLA-DR ${ }_{2}$, and there are documented differences in Caucasians and Orientals with MS patients in terms of HLA association and oligoclonal bands (OCBs) ${ }^{13-15}$.

There have been relatively a few studies from Asia, India ${ }^{16}$ and in particular no study from Bangladesh. Asian MS has traditionally been thought of as a distinct entity characterized by optic nerve and spinal cord involvement, with predominant visual involvement in the beginning being more common ${ }^{17}$ and less frequent involvement of cerebellum ${ }^{18-22}$.

Clinical pattern of multiple sclerosis in Bangladesh is unknown. However, the detection of MS have increased as a consequence of use of modern investigative facilities, particularly with the availability of MRI facilities, increased awareness among medical professionals and patients.

\section{Aims and Objectives}

Many studies are available from other countries of Asia, especially from Japan, Saudi Arabia and India. There has been no study from Bangladesh. The aims of this study was to find out and describe the initial symptoms of multiple sclerosis and compare the observed clinical features between Bangladeshi MS patients with those of the western MS patients.

\section{Materials and Methods}

This prospective study was carried out in the Department of Neurology, Bangabandhu Sheikh Mujib Medical University (BSMMU), Dhaka, among both indoor and outdoor patients, during the period of January 2002 to December 2003. A total number of 25 patients were assessed, investigated and diagnosed having MS during the study period, who fulfilled the McDonald's diagnostic criteria for multiple sclerosis ${ }^{23}$. Patients with recent vaccination and/or viral infection, patients suffering from systemic lupus erythematosus (SLE), Rheumatoid arthritis (RA), sarcoidosis and other collagen vascular disease, neoplasm, cervical spondylosis and metabolic disorders were excluded from the study.

Clinical diagnosis of MS patients was based on medical history and clinical examination. Confirmation of clinical diagnosis was done by available relevant investigations, specially MRI of brain and/or spinal cord with contrast when required. Necessary laboratory procedures were done to ascertain exclusion criteria.

Informed consents were taken from each patient before his/her inclusion in the study. All relevant information from history, clinical findings and investigations were documented in predesigned data collection 
sheet. Patients were seen every three months interval or as required in the Department of Neurology, BSMMU, and subsequent data recorded in the data collection sheet. Data collected were compiled in a master sheet and required analyses were done using computer based software SPSS (Statistical Package for Social Science).

\section{Results}

The age range of 25 patients of MS was 10 65 years, with mean $( \pm S D) 30.56 \pm 13.44$ years. The study included $8(32 \%)$ cases $\leq 20$ years, $12(48 \%)$ cases between 21 40 years, $4(16 \%)$ cases between 41-60 years and 1 (4\%) case above 60 years. The peak age of incidence of MS was found in 21-40 years age group (Table I).

Table-I

Age distribution of the study subjects $(n=25)$

\begin{tabular}{lcc}
\hline $\begin{array}{l}\text { Age group } \\
\text { (years) }\end{array}$ & $\begin{array}{c}\text { Number of } \\
\text { patients }\end{array}$ & Percentage \\
\hline$\leq 20$ & 8 & 32.0 \\
$21-40$ & 12 & 48.0 \\
$41-60$ & 4 & 16.0 \\
$>60$ & 1 & 4.0 \\
\hline Total & 25 & 100 \\
\hline
\end{tabular}

Out of 25 patients of MS, 12 (48\%) were male and 13 (52\%) were female. The male female ratio was 1:1.08 (Table II).

Table II

Sex distribution of the cases $(n=25)$

\begin{tabular}{lcc}
\hline Sex & $\begin{array}{c}\text { Number of } \\
\text { patients }\end{array}$ & Percentage \\
\hline Male & 12 & 48.0 \\
Female & 13 & 52.0 \\
\hline Total & 25 & 100 \\
\hline
\end{tabular}

The lesions at initial onset are shown in Table III. Sixteen (64\%) patients out of 25 had optic neuritis as their first symptom. Five (20\%) patients had optic neuritis alone. Seven (28\%) patients had optic nerve and brain, 4 (16\%) patients had optic nerve and spinal cord involvement at onset. Seven (28\%) patients had myelitis alone, 1 (4\%) had spinal cord and brain involvement, and $1(4 \%)$ had only brain involvement.

Table-III

Lesions at initial onset among Bangladeshi multiple sclerosis patients $(n=25)$

\begin{tabular}{lcc}
\hline First involvement & $\begin{array}{c}\text { Number of } \\
\text { patients }\end{array}$ & Percentage \\
\hline Only optic nerve & 5 & 20.0 \\
Optic nerve + brain & 7 & 28.0 \\
Optic nerve + spinal cord & 4 & 16.0 \\
Only spinal cord & 7 & 28.0 \\
Spinal cord + brain & 1 & 4.0 \\
Brain alone & 1 & 4.0 \\
Optic nerve involvement $(\mathrm{n}=16)$ & \\
Unilateral & 8 & 50.0 \\
Bilateral & 8 & 50.0 \\
\hline
\end{tabular}

Table IV shows mode of onset among the study subjects. Out of 25 cases, 14 (56\%) had acute onset, 7 (28\%) subacute onset and $4(16 \%)$ chronic or insidious onset.

Table IV

Multiple sclerosis typing (according to mode of onset) $(n=25)$

\begin{tabular}{lcc}
\hline Mode of onset & $\begin{array}{c}\text { Number of } \\
\text { patients }\end{array}$ & Percentage \\
\hline Acute & 14 & 56.0 \\
Subacute & 7 & 28.0 \\
Chronic/insidious & 4 & 16.0 \\
\hline Total & 25 & 100 \\
\hline
\end{tabular}

In Table $\mathrm{V}$, the number of previous attack has been shown. Out of 25 patients, 5 
(20\%) had one, 8 (32\%) had two and 5 (20\%) had more than two previous attacks. Seven (28\%) patients had no history of previous attack.

Table-V

Distribution of the respondents by number of previous attacks ( $n=25)$

Previous attacks Number of Percentage patients

\begin{tabular}{lcc}
\hline One & 5 & 20.0 \\
Two & 8 & 32.0 \\
More than two & 5 & 20.0 \\
None & 7 & 28.0 \\
\hline Total & 25 & 100 \\
\hline
\end{tabular}

Table VI shows the course of the disease among the respondents. Fifteen (60\%) cases had relapsing remitting course, 7 (28\%) had secondary progressive course and $3(12 \%)$ had primary progressive multiple sclerosis.

Table-VI

Distribution of the cases according to course of the disease $(n=25)$

\begin{tabular}{lcc}
\hline Disease course & $\begin{array}{c}\text { Number of } \\
\text { patients }\end{array}$ & Percentage \\
\hline $\begin{array}{l}\text { Relapsing } \\
\text { remitting MS }\end{array}$ & 15 & 60.0 \\
$\begin{array}{l}\text { Secondary } \\
\text { progressive MS }\end{array}$ & 7 & 28.0 \\
$\begin{array}{l}\text { Primary } \\
\text { progressive MS }\end{array}$ & 3 & 12.0 \\
\hline Total & 25 & 100 \\
\hline
\end{tabular}

The clinical presentations are summarized in Table VII. Out of 25 study cases, 23 (92\%) had motor weakness, 10 (40\%) had both upper and lower limbs weakness, 13 (52\%) had only lower limbs involvement,
$20(80 \%)$ had rigidity of their limbs. Sensory symptoms, like numbness and paresthesia, diminished or loss of sensation, were found in following order respectively (84\%, 60\% and 4\%). Impaired vision was found in 16 (64\%) cases. Seven $(28 \%)$ cases had pain in their eyes. Symptoms like ataxia, sphincteric disturbance, paroxysmal attack were found in a large number of patients $\{8$ (32\%), 23 (92\%), 8 (32\%), respectively\}.

Table-VII Clinical presentation $(n=25)$

\begin{tabular}{lcc}
\hline Presentation & $\begin{array}{c}\text { Number of } \\
\text { patients }\end{array}$ & Percentage \\
\hline Weakness & & \\
Upper + lower limb & 10 & 40.0 \\
Only lower limb & 13 & 52.0 \\
Only upper limb & 0 & 0 \\
No weakness & 2 & 8.0 \\
Rigidity & 20 & 80.0 \\
Sensory function & & \\
Diminished & 15 & 60.0 \\
Lossed & 1 & 4.0 \\
Normal & 9 & 36.0 \\
Numbness/paresthesia & 21 & 84.0 \\
Impaired vision & 16 & 64.0 \\
Both eyes & 8 & 32.0 \\
Only left eye & 3 & 12.0 \\
Only right eye & 5 & 20.0 \\
Pain in the eyes & & \\
Only right eye & 1 & 4.0 \\
Only left eye & 1 & 4.0 \\
Both eyes & 5 & 20.0 \\
Diplopia & 1 & 4.0 \\
Ataxia & 8 & 32.0 \\
Urinary Sphincteric & 23 & 92.0 \\
Disturbance & & \\
Urgency & 7 & 28 \\
Incontinence & 5 & 20 \\
Retention & 5 & 20 \\
Frequency & 3 & 12 \\
Hesitancy & 3 & 32.0 \\
Paroxysmal attack \\
(painful tonic spasm)
\end{tabular}

Functional status of the study patients has been shown in Table VIII. Nine (36\%) patients had restricted activities, 7 (28\%) 
were bedridden, 3 (12\%) were chairbound, 4 (16\%) suffered only minor disabilities and were still in work, and 1 (4\%) had died.

Table-VIII

Present functional status ( $n=25)$

\begin{tabular}{lcc}
\hline Function Status & $\begin{array}{c}\text { Number of } \\
\text { patients }\end{array}$ & Percentage \\
\hline Restricted activity & 9 & 36.0 \\
Bedridden & 7 & 28.0 \\
Chairbound & 3 & 12.0 \\
Minor disability & 4 & 16.0 \\
Normal activity & 1 & 4.0 \\
Expired & 1 & 4.0 \\
\hline Total & 25 & 100 \\
\hline
\end{tabular}

\section{Discussion}

Multiple sclerosis is an uncommon condition in Bangladesh, and its prevalence, incidence and other demographic data remains to be determined. So far my knowledge goes no study has yet been published on multiple sclerosis in Bangladesh. The present study disclosed that certain clinical features of multiple sclerosis patients are different from those of multiple sclerosis patients in western countries, but the age distribution in Bangladeshi multiple sclerosis patients were not significantly different from those of western and other Asian countries 24,25.

The present study was carried out to find out the initial symptoms of multiple sclerosis among Bangladeshi patients. The study subjects were taken from the Department of Neurology (both indoor and outdoor), Bangabandhu Sheikh Mujib Medical University (BSMMU), Dhaka. During the study period, from January 2002 to December 2003, 25 multiple sclerosis patients were evaluated. Patients were selected by McDonald et al. diagnostic criteria for multiple sclerosis ${ }^{23}$. Clinical examination and laboratory investigations were done in all patients.

In this study, 12 (48\%) patients were male and 13 (52\%) were female (ratio 1:1.08). There was no marked female preponderance like other countries. The male female ratio in various countries are USA 1:1.8 26 , Northern Ireland 1:1327, US army $1: 1.8^{28}$, Japan $1: 1.3^{29}$, Taiwan $1: 3.2^{30}$, Hawaii $1: 3.2^{31}$, India $1: 3^{32}$ and Thailand $1: 3^{25}$. The male female ratio is higher in our country than western and oriental countries. Predominant male health seeking behaviour and also less allocation of hospital beds for female patients in country may explain the above. These findings are not consistent with those of Acheson, who previously pointed out that the preponderance of female over male patients seemed to be greater where the incidence of multiple sclerosis was low than where it was high ${ }^{27}$.

We did not find any familial case. This may be because of multiple sclerosis began to be diagnosed during last few years in our country, and general population has no idea about this disease.

With regard to initial lesion, this study showed that optic neuritis $(16 / 25,64 \%)$ was common initial lesion among the Bangladeshi multiple sclerosis patients. Five (20\%) patients had optic neuritis alone, seven (28\%) had optic nerve and brain involvement, four (16\%) had optic nerve and spinal cord involvement. It was $43 \%$ in Japanese nationwide series, $14 \%$ in Israel, $43 \%$ in Brazil, $36 \%$ in Germany, $56 \%$ in Taiwan, 28\% among UK army and $25 \%$ in the USA $24,30,33-35$. 
Optic neuritis was lower than Thai series $(68 \%)$ as shown by Jitpimolmard and Vejjajivaas ${ }^{25}$, which is almost equal to Korean patients, where it was $64 \%{ }^{36}$. It is interesting that the incidence of optic neuritis when combined with spinal cord and brain involvement, it was even higher among Bangladeshi patients. Though multiple sclerosis is not different from the western variety, an increased frequency of visual involvement is a common feature in Asian variety ${ }^{32}$. Seven (28\%) patients had only spinal cord involvement presented initially as myelitis, which is comparable in percentage with the other series $(28.46 \%)^{37}$.

The frequency of brainstem and cerebellar lesions were much lower than the US army, Brazil, USA, Japan, China and Taiwan. This is because of the use of brainstem evoked potential in developed countries that unmasked the silent lesion in the brainstem. Twenty three (92\%) patients developed weakness of the limbs. It is much higher than Germany $(43 \%)^{35}$, USA $(54 \%)^{24}$, Japan $(24 \%)^{34}$ and Taiwan $(40 \%)^{30}$ series. This is because that our patients usually presents late in the disease course.

Sphincteric abnormalities in the present group differs extensively from reported series in other countries. It was $22 \%$ in Brazil $^{38}, 10 \%$ in Germany ${ }^{35}, 30 \%$ in the USA $^{24}, 4 \%$ in Taiwan $^{30}$ and $23 \%$ in Korea $^{36}$.

One of the striking feature of this study was the high incidence of painful tonic seizure (PTS), specially in cases with severe spinal cord involvement. This phenomenon was seen in $8(32 \%)$ patients out of 25 multiple sclerosis cases.
Shibasaki and Kuroiwa ${ }^{39}$ found the condition in $11(17.2 \%)$ patients out of a consecutive series of 64 patients with multiple sclerosis, a much higher incidence than has been found in western countries ${ }^{28}$. In Thailand, Jitpimolmard and Vejjajiva ${ }^{25}$ observed no less than 3 in 15 patients with multiple sclerosis. It appears, therefore, that PTS is relatively frequent among multiple sclerosis patients in Bangladesh and in Asian countries where cases with severe spinal cord involvement are more frequently encountered.

\section{Conclusion}

Multiple sclerosis is a leading neurological disease causing chronic disability in young adults, especially in western countries, which might cost a large amount of money each year.

It has been established that multiple sclerosis in Bangladesh exhibits some clinical difference in its initial neurological symptoms from those of western countries but not from most of the Asian countries, which may be due to racial, genetic and environmental influences.

\section{References}

1. Frohman EM. Multiple sclerosis. Med N Am 2003; 867 -97, viii-ix.

2. Minderhoud JM, van der Hoeven $\mathrm{JH}$, Prange AJ. Course and prognosis of chronic progressive multiple sclerosis: results of an epidemiological study. Acta Neurol Scand 1988; 78:10-15.

3. Kurland LT. The epidemiologic characteristics of multiple sclerosis. In: Vinken PJ, Bruyn GW, editors. Handbook of clinical neurology. Amsterdam: North Holland Publishing Co., 1970: pp 63-84. 
4. Anderson DW, Ellenberg $\mathrm{JH}$, Leventhal CM. Revised estimate of the prevalence of multiple sclerosis in the United States. Ann Neurol 1992; 31:3333 -6.

5. Yaqub BA, DaifAK. Multiple sclerosis in Saudi Arabia. Neurology 1988; 38:621-3.

6. Al Rajeh S, Bademosi O, Ismail H. A community survey of neurological disorders in Saudi Arabia: the Thugbah study. Neuroepidemiology 1993; 12:164 -78.

7. Al Din ASN, El Khateeb M, Kurdi A. Multiple sclerosis in Arabs in Jordan. J Neurol Sci 1995; 131:144 -9.

8. Warren S. Epidemiology of multiple sclerosis. In: Anderson DW, editor. Boca Raton: CRC Press, 1991: pp.239-64.

9. Poser CM. The epidemiology of multiple sclerosis: a general overview. Ann Neurol 1994; 36(Suppl 2):S18093.

10. Okinaka S, Tsubaki T, Kuroiwa Y, Toyokura Y, Imamarua Y, Yoshikawa M. Multiple sclerosis and its allied diseases in Japan: clinical characteristics. Neurology (Minneap) 1958; 8:756-63.

11. Shiraki H, Yamamoto T, Hamada S. Pathological studies on neuromyelitis optica and demyelinating myelitis in Japan: the relationship of neuromyelitis optica to multiple sclerosis. Psychiat Neurol Jpn 1958; 60:1-49.

12. Kuroiwa Y. Multiple sclerosis and allied demyelinating encephalo- myelitis in Japan. In: Zukunft der Neurologie, Stuttgart, Georg Thieme Varlag, 1967: pp.70-84.

13. Kelly MA, Jacob KH, Penny MA. An investigation of HLA encoded genetic susceptibility to multiple sclerosis in subjects of Asian, Indian and AfroCarribbean ethnic origin. Tissue Antigens 1995; 45:197-202.

14. Kelly MA, Zhang Y, Penny MA. Genetic susceptibility to multiple sclerosis in Shanghai Chinese population: the role of HLA Class II genes. Hum Immunol 1995; 4:203-8.

15. Yu YL, Woo E, Hawkins BR. Multiple sclerosis amongest Chinese in Hong Kong. Brain 1989; 112:1445-67.

16. Syal $P$, Probhakar $S$, Thussu A, Khandalwal N. Clinical profile of multiple sclerosis in North West India. Neurol India 1999; 47: 12-7.

17. Gangopadhyay G, Das SK, Sarda P, Saha SP, Gangopadhyay P, Roy TN, et al. Clinical profile of multiple sclerosis in Bengal. Neurol India 1999; 47:18-21.

18. Chopra JS, Radhakrishnan K, Sawhney BB. Multiple sclerosis in Northwest India. Acta Neurol Scand 1980; 62: 312-21.

19. Kuroiwa $Y$, Shibashaki $H$, Tabira T. Clinical picture of multiple sclerosis in Asia. In: Kuroiwa Y, Kurland LT, editors. Fukuoka: Kyushu University Press, 1982: pp.43-47.

20. Kuroiwa $Y$, Igata A, Itahara K. Nationwide survey of multiple sclerosis in Japan: clinical analysis of 1084 cases. Neurology, Minneapolis 1975; 25:845-51. 
21. Mathew NT, Mathai KV, Abraham J. Incidence and pattern of demyelinating disease in India. J Neurol Sci 1971; 13:27-38.

22. Singhal BS. Multiple sclerosis and related demyelinating disorders in Indian context. Neurol India 1987; 35:1-12.

23. McDonald WI, Compston A, Edan G. Recommended diagnostic criteria for multiple sclerosis: guidelines from the international panel on the diagnosis of multiple sclerolsis. Ann Neurol 2001; 50:121-7.

24. Kurtzke JF, Beebe GW, Nagler B, Auth TL, Kurland LT, Neiger MD. Studies on natural history of multiple sclerosis. Acta Neurol Scand 1972; 48:19-46.

25. Jitpimolmard S, Vejjajiva A. Clinical features and clinical course of multiple sclerosis in Thai patients: a report of 50 cases. J Med Assoc Thai 1994; 77:239-42.

26. Kurtzke JF, Beebe GW, Normal JE. Epidemiology of multiple sclerosis in US veterans. Neurology 1979; 29:1228-35.

27. Acheson ED. The pattern of the disease. In: Matthews WB, Acheson ED, editors. McAlpine's multiple sclerosis. Edinburgh: Churchill Livingstone, 1985: pp.1-26.

28. McAlpine D. Multiple sclerosis: a reappraisal. In: McAlpine $D$, Lumsden C, editors. Part 1, 2nd ed. London: Churchill Livingstone, 1972: pp.83-307.

29. Kuroiwa Y, Shibasaki H. Clinical studies of multiple sclerosis in Japan. I. A current appraisal of 63 cases. Neurology (Minneap) 1973; 23:609-17.
30. Hung TP, Landsborough D, Hsi MO. Multiple sclerosis in Taiwan. J Neurol Sci 1976; 27:459-84.

31. Alter M, Okihiro M, Rowley $\mathrm{Wm}$, Morris T. Multiple sclerosis among Orientals and Caucasians in Hawaii. Neurology 1971; 31:122-30.

32. Singhal BS, Wadia NH. Profile of multiple sclerosis in the Bombay region. J Neurol Sci 1975; 26:259-70.

33. Leibowitz $U$, Alter M. Multiple sclerosis. Clues to its cause. Amsterdam: North Holland Publishing Co., 1973: pp.345-72.

34. Kuroiwa $Y$, Igata $A$, Itahara $K$, Kishijima S, Tsubaki T, Toyokura $Y$, et al. Nationwide survey of multiple sclerosis in Japan: clinical analysis of 1084 cases. Neurology 1975; 25:845-51.

35. Bauer HJ. Problems of symptomatic therapy of multiple sclerosis. Neurology 1978; 28:8-20.

36. Kurtzke JF, Park CS, Oh SJ. Multiple sclerosis in Korea: clinical features and prevalence. J Neurol Sci 1968; 6:463-81.

37. Kurtzke JF. A reassessment of the distribution of multiple sclerosis. Part I and II. Acta Neurol Scand 1975; 51:110-36, 137-57.

38. Lana Peixoto MA, Lana Peixoto MI. Is multiple sclerosis in Brazil and Asia alike? Arq Neuro Psiquiat (Säo Paulo) 1992; 50:419-25.

39. Shibasaki H, Kuroiwa Y. Painful tonic seizure in multiple sclerosis. Arch Neurol 1974; 30:47-51. 